\title{
Particulate matter concentrations and their association with COVID-19-related mortality in Mexico during June 2020 Saharan dust event
}

\author{
Gurusamy Kutralam-Muniasamy ${ }^{1} \cdot$ Fermín Pérez-Guevara $^{1,2} \cdot$ Ignacio Elizalde Martínez $^{3} \cdot{\text { Shruti Venkata } \text { Chari }^{3}}^{3}$
}

Received: 25 February 2021 / Accepted: 26 April 2021 / Published online: 4 May 2021

(C) The Author(s), under exclusive licence to Springer-Verlag GmbH Germany, part of Springer Nature 2021

\begin{abstract}
The present study evaluated the impact of Saharan dust event on particulate matter (PM: $\mathrm{PM}_{10}$ and $\left.\mathrm{PM}_{2.5}\right)$ concentrations by analyzing the daily average PM data between Saharan dust days (June 23-29, 2020) and non-Saharan dust days (June 15 to June 22 and June 30 to July 12, 2020) for four majorly affected regions in Mexico and by comparing with three major previous events $\left(2015,2018\right.$, and 2019). The results showed that $\mathrm{PM}_{10}$ and $\mathrm{PM}_{2.5}$ concentrations were $2-5$ times higher during the Saharan dust event with the highest daily averages of $197 \mu \mathrm{g} / \mathrm{m}^{3}$ and $94 \mu \mathrm{g} / \mathrm{m}^{3}$, respectively, and exceeded the Mexican standard norm (NOM-020-SSA1-2014). When comparing with the previous Saharan dust episodes of 2015, 2018, and 2019, the levels of $\mathrm{PM}_{10}$ and $\mathrm{PM}_{2.5}$ considerably increased and more than doubled across Mexico. The correlation analysis revealed a positive association of PM levels with the number of daily COVID-19 cases and deaths during Saharan dust event. Furthermore, the human health risk assessment showed that the chronic daily intake and hazard quotient values incremented during Saharan dust days compared to non-Saharan days, indicating potential health effects and importance of taking necessary measures to ensure better air quality following the COVID-19 pandemic.
\end{abstract}

Keywords Air pollution $\cdot \mathrm{PM}_{2.5} \cdot \mathrm{PM}_{10} \cdot$ Air quality index $\cdot$ Public health $\cdot$ Hazard quotient

\section{Introduction}

Air pollution remains a global environmental threat and a public health risk. The World Health Organization (WHO) estimated that exposure to polluted air alone caused around 4.2 million deaths worldwide in 2016 (WHO 2018). Particulate matter (PM) is one of the most common air

Responsible Editor: Lotfi Aleya

Shruti Venkata Chari

shrutifrnd@gmail.com

1 Department of Biotechnology and Bioengineering, Centro de Investigación y de Estudios Avanzados del Instituto Politécnico Nacional, Ciudad de México, México

2 Nanoscience \& Nanotechnology Program, Centro de Investigación y de Estudios Avanzados del Instituto Politécnico Nacional, Ciudad de México, México

3 Instituto Politécnico Nacional (IPN), Centro Mexicano para la Producción más Limpia (CMP+L), Av. Acueducto s/n, Col. Barrio la Laguna Ticomán, Del Gustavo A. Madero, C.P. 07340, México, D.F., México pollutants which comprises particles of various sizes $\left(\mathrm{PM}_{10}\right.$ and $\mathrm{PM}_{2.5}$ ) with associated adsorbed substances (i.e., chemicals and metals). PM can be naturally originated (i.e., sea spray, volcanoes, forests, and deserts) and anthropogenic originated (i.e., vehicles, combustion, industry, and power plants) (Hernández-Escamilla et al. 2015; Ali-Khodja et al. 2017). With the increase in anthropogenic activities and ambient PM concentrations, their exposure to short-term and long-term period affects human health and contributes breathing problems, respiratory diseases, chronic diseases, cancer, and premature mortality (Kim et al. 2015; Loxham and Nieuwenhuijsen 2019). The impact of desert dust events on the PM concentrations and human health has received worldwide attention in the last decades. Sahara Desert is the largest source of atmospheric mineral dust and dust storms are a common meteorological phenomenon, happening especially between late Spring and early Fall, peaking in late June to mid-August (Querol et al. 2019; Çapraz and Deniz 2020). It has been estimated that about 800 millions of metric tons of dust from North Africa travel and impact across the Atlantic Ocean, the Mediterranean Sea, and the Red Sea, to the Caribbean, South America, North America, Europe, and the 
Middle East every year (Querol et al. 2019; Çapraz and Deniz 2020). Owing to the frequent long-range transport of large amounts of dust, a number of studies have evaluated the impact of Saharan dust events on PM concentrations (Querol et al. 2009; Achilleos et al. 2014; Moroni et al. 2015; Dimitriou and Kassomenos 2018; Querol et al. 2019). It is understood from these studies that Sahara dust events greatly increase the ambient concentration of PM contributing to air pollution and may be associated with adverse health effects.

According to NOAA's (National Oceanic and Atmospheric Administration) Atlantic Oceanographic and Meteorological Laboratory, the June 2020 Saharan dust event was around $60-70 \%$ dustier than an average event happened in 20 years. Most notably, the June 2020 Saharan dust occurred at a critical time when the world is already facing Coronavirus disease 2019 (COVID-19), a global health crisis. COVID-19 is an acute respiratory disease caused by SARSCoV-2 (WHO 2020); it has been suggested that environmental factors, such as ambient air pollution, could increase the severity of the health outcomes (e.g., hospitalization and death) among individuals with COVID-19 (Coker et al. 2020). Recent researchers have corroborated the presence of SARS-CoV-2 viral RNA on coarse PM and associations with COVID-19 mortality cases (Setti et al. 2020; Wu et al. 2020). Several studies identified positive association between higher $\mathrm{PM}_{2.5}$ and $\mathrm{PM}_{10}$ and COVID-19 deaths globally (Yao et al. 2020; Wu et al. 2020). With the rapid emergence of the novel COVID-19 disease, which by itself is a respiratory disease, it will be important to evaluate the impact of June 2020 Saharan dust event on PM levels and to determine if any relevant associations with COVID-19 cases and deaths. The Saharan dust event occurred between June 23 and June 29, 2020 in Mexico, right after the withdrawal of COVID-19 lockdown, has drawn our attention. Air pollution has been a primary issue in Mexico, exceeding the WHO-recommended level in relation to various types of air pollutants, including the PM, in most of its major cities (Molina et al. 2019). The Saharan dustaffected regions include the parts of northeastern Mexico and Yucatan Peninsula (Fig. 1), where they already have higher levels of air pollution due to industrialization and urbanization activities (González-Santiago et al. 2011; Bretón et al. 2018; CONAGUA 2020). Thus, the main objectives of this study are (1) to examine the relative contribution of Saharan dust on $\mathrm{PM}_{10}$ and $\mathrm{PM}_{2.5}$ concentrations, (2) to assess the variations in PM concentrations when compared with previous major dust episodes $(2015,2018$, and 2019), (3) to explore the association of PM concentrations with COVID-19 cases and deaths, and (4) to evaluate the human health risk associated with PM exposure via inhalation. To the best of our knowledge, this is the first research to document the impact of Saharan dust event in relation to PM levels $\left(\mathrm{PM}_{10}\right.$ and $\mathrm{PM}_{2.5}$ ) and human health in Mexico and during COVID-19 crisis.

\section{Methodology}

\section{Site description and data collection}

In this study, the PM levels $\left(\mathrm{PM}_{10}\right.$ and $\left.\mathrm{PM}_{2.5}\right)$ for a total of 28 days between June 15, 2020 and July 12, 2020 were assessed in four majorly hit regions of Mexico, namely, Nuevo Leon, Veracruz, Tabasco, and Yucatan (Fig. 1b). The period between June 23 and June 29, 2020 when the event took place in Mexico was considered as Saharan dust days, whereas the periods prior (June 15 to June 22) and after the event (June 30 to July 12, 2020) were collectively considered as non-Saharan dust days. For our analysis, we used the daily concentrations of $\mathrm{PM}_{10}$ and $\mathrm{PM}_{2.5}$ as well as the meteorological data (i.e., temperature, relative humidity, and wind speed) during the study period from 15 air monitoring stations located in Nuevo Leon $(n=11)$, Veracruz $(n=2)$, Tabasco $(n=1)$, and Yucatan $(n=1)$, respectively. The details and data availability of the monitoring stations are provided in Table 1 . The previous major Saharan dust episodes in Mexico, recorded in the years of 2015, 2018, and 2019, were considered for the comparison of PM levels with that of 2020. The PM data for Saharan dust events during 2015, 2018, 2019, and 2020 was downloaded from the website of Sistema Nacional de Información de la Calidad del Aire (SINAICA, https:// sinaica.inecc.gob.mx/index.php), operated by Instituto Nacional de Ecologia y Cambio Climatico, Government of Mexico.

To find associations, if any, of PM levels with COVID19 cases and mortality, we collected the data of confirmed COVID-19 cases and deaths (June 15, 2020 to July 12, 2020) from the official website of the Government of Mexico (https://coronavirus.gob.mx/datos/). We preferred to carry out this analysis only for Nuevo Leon as the dataset available from monitoring stations $(n=11)$ covers the wider province comparatively higher than other states selected in this study. Additionally, it represents the third most populated region in Mexico. Statistical analysis was conducted using Statistica software (version 8.0). The whole data set was varimax normalized to minimize the number of variables with a high loading on each component. Correlation matrix with $p<0.5,0.01,0.001$ values was obtained to investigate the relationships between the PM levels and COVID-19 cases and deaths.

\section{Air quality index}

Air quality index (AQI) by USEPA (1999) was employed for the effective assessment of air quality. We calculated AQI for $\mathrm{PM}_{10}$ and $\mathrm{PM}_{2.5}$ obtained from each monitoring stations using the following equation: 


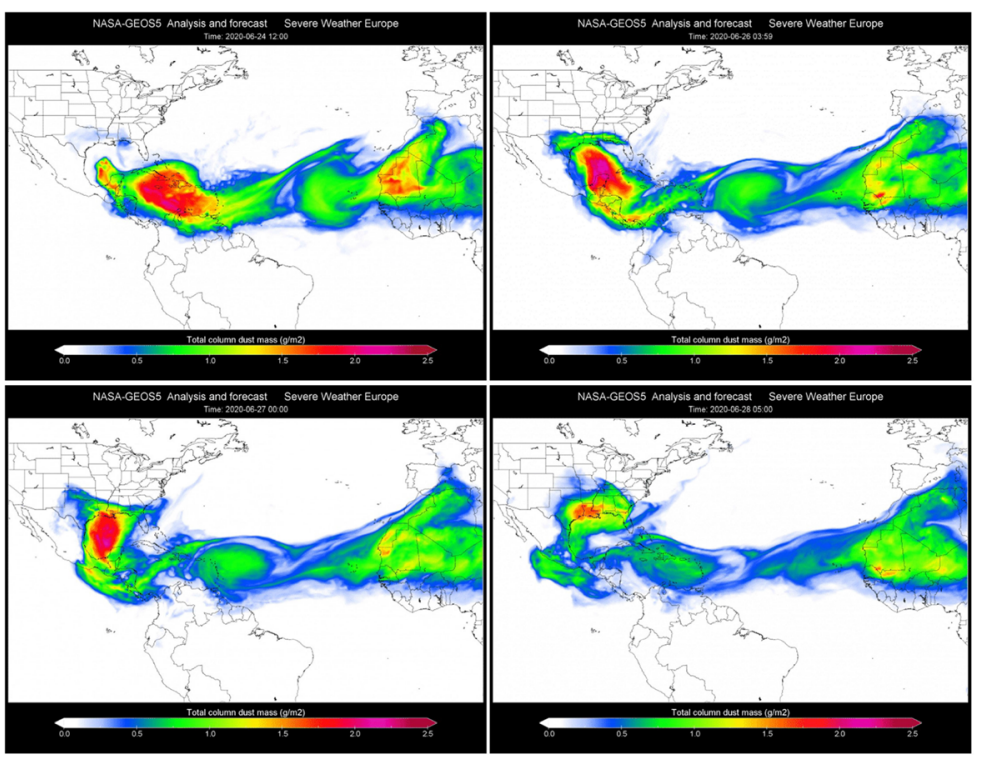

(a)

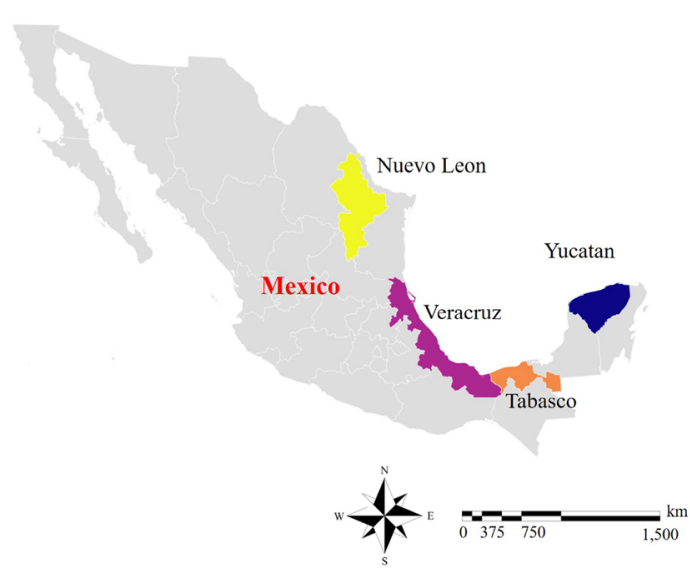

(b)

Fig. 1 a Dust forecast obtained from the NASA GEOS-5 model showing the June 2020 Saharan dust event. b Map showing the study regions for the demonstration of Saharan dust event in Mexico

$I_{\mathrm{p}}=\frac{I_{\mathrm{Hi}}-I_{\mathrm{Lo}}}{B P_{\mathrm{Hi}}-B P_{\mathrm{Lo}}}\left(C_{\mathrm{p}}-B P_{\mathrm{Lo}}\right)+I_{\mathrm{Lo}}$

where $I_{\mathrm{p}}=$ index for pollutant $p ; C_{\mathrm{p}}=$ rounded concentration of pollutant $p ; B P_{\mathrm{Hi}}=$ the breakpoint that is greater than or equal to $C_{\mathrm{p}} ; B P_{\mathrm{Lo}}=$ the breakpoint that is less than or equal to $C_{\mathrm{p}} ; I_{\mathrm{Hi}}=$ the $\mathrm{AQI}$ value corresponding to $B P_{\mathrm{Hi}} ; I_{\mathrm{Lo}}=$ the $\mathrm{AQI}$ value corresponding to $B P_{\mathrm{Lo}}$. The AQI ranges from 0 to 500 and categorized into following six intervals: 0-50: good (air quality is good with no risk); 51-100: moderate (air quality is acceptable; however, for some pollutants, there may be a moderate health concern like for people having respiratory diseases); 101-150: unhealthy for sensitive groups (members of sensitive groups may experience health effects); 151200: unhealthy (everyone may begin to experience health effects); 201-300: very unhealthy (health warnings of emergency conditions and the entire population is more

Table 1 List of air monitoring stations from the Saharan dust-affected regions for the period of assessment (June 15-July 12, 2020) in Mexico

\begin{tabular}{|c|c|c|c|c|}
\hline State & Air monitoring station & $\begin{array}{l}\text { Short } \\
\text { name }\end{array}$ & Data availability & $\begin{array}{l}\text { Latitude and } \\
\text { longitude }\end{array}$ \\
\hline \multirow{11}{*}{$\begin{array}{l}\text { Nuevo } \\
\text { Leon }\end{array}$} & Apodaca & MAS 1 & $\mathrm{PM}_{10}, \mathrm{PM}_{2.5}$, temperature, wind speed and relative humidity & $25.78 \mathrm{~N}, 100.19 \mathrm{~W}$ \\
\hline & Cadereyta & MAS 2 & $\mathrm{PM}_{10}, \mathrm{PM}_{2.5}$, temperature, wind speed and relative humidity & $25.60 \mathrm{~N}, 99.99 \mathrm{~W}$ \\
\hline & Garcia & MAS 3 & $\mathrm{PM}_{10}, \mathrm{PM}_{2.5}$, temperature, wind speed and relative humidity & $25.78 \mathrm{~N}, 100.59 \mathrm{~W}$ \\
\hline & Juarez & MAS 4 & $\mathrm{PM}_{10}, \mathrm{PM}_{2.5}$, temperature and wind speed & $25.65 \mathrm{~N}, 100.1 \mathrm{~W}$ \\
\hline & La Pastora & MAS 5 & $\mathrm{PM}_{10}, \mathrm{PM}_{2.5}$, temperature, wind speed and relative humidity & $25.67 \mathrm{~N}, 100.25 \mathrm{~W}$ \\
\hline & Obispado & MAS 6 & $\mathrm{PM}_{10}$, temperature, wind speed and relative humidity & $25.68 \mathrm{~N}, 100.34 \mathrm{~W}$ \\
\hline & Pueblo Serena & MAS 7 & $\mathrm{PM}_{10}$, temperature, wind speed and relative humidity & $25.58 \mathrm{~N}, 100.25 \mathrm{~W}$ \\
\hline & San Bernabe & MAS 8 & $\mathrm{PM}_{10}, \mathrm{PM}_{2.5}$, temperature, wind speed and relative humidity & $25.76 \mathrm{~N}, 100.37 \mathrm{~W}$ \\
\hline & San Pedro & MAS 9 & $\mathrm{PM}_{10}, \mathrm{PM}_{2.5}$, temperature, wind speed and relative humidity & $25.67 \mathrm{~N}, 100.41 \mathrm{~W}$ \\
\hline & Santa Catarina & MAS 10 & $\mathrm{PM}_{10}, \mathrm{PM}_{2.5}$, temperature, wind speed and relative humidity & $25.68 \mathrm{~N}, 100.46 \mathrm{~W}$ \\
\hline & Universidad & MAS 11 & $\mathrm{PM}_{10}$, temperature, wind speed and relative humidity & $25.73 \mathrm{~N}, 100.31 \mathrm{~W}$ \\
\hline \multirow[t]{2}{*}{ Veracruz } & Universidad Veracruzana & VAS 1 & $\mathrm{PM}_{10}, \mathrm{PM}_{2.5}$, temperature, wind speed and relative humidity & $20.51 \mathrm{~N}, 97.45 \mathrm{~W}$ \\
\hline & Minatitlan Tecnologico & VAS 2 & $\mathrm{PM}_{2.5}$, temperature, wind speed and relative humidity & $18.01 \mathrm{~N}, 94.56 \mathrm{~W}$ \\
\hline Tabasco & $\begin{array}{l}\text { Instituto Tecnologico de } \\
\text { Villahermosa }\end{array}$ & TAS & $\mathrm{PM}_{10}$ & $18.02 \mathrm{~N}, 92.9 \mathrm{~W}$ \\
\hline Yucatan & Merida SDS01 & YAS & $\mathrm{PM}_{2.5}$, temperature and relative humidity & $20.97 \mathrm{~N}, 89.62 \mathrm{~W}$ \\
\hline
\end{tabular}


likely to be affected); and 301-500: hazardous (everyone may experience more serious health effects).

\section{Human health risk assessment on exposure to particulate matter $\left(\mathbf{P M}_{10}\right.$ and $\left.\mathbf{P M}_{2.5}\right)$}

\section{Exposure dose}

Human health risk assessment (USEPA 1989) was performed to understand the nature and probability of adverse health effects in humans exposed to PM during the June 2020 Saharan dust event. We concentrated on the health risk estimation through inhalation route for both children and adults. Chronic daily intake (CDI) was estimated for assessing the human health risk upon exposure to PM through inhalation pathway. It was calculated as follows (USEPA 2009):

$C D I_{\text {inh }}=C_{\mathrm{UCL}} \times \frac{R_{\text {inh }} \times F_{\text {exp }} \times T_{\text {exp }}}{A B W \times T_{\text {avrg }}}$

where $\mathrm{CDI}=$ chronic daily intake $\left(\mu \mathrm{g} \mathrm{kg}^{-1}\right.$ day $\left.^{-1}\right) ; R_{\text {inh }}=$ inhalation rate at $20 \mathrm{~m}^{3}$ day $^{-1}$ for adults and $7.6 \mathrm{~m}^{3}$ day $^{-1}$ for children; $F_{\text {exp }}=$ exposure frequency $\left(\right.$ days year ${ }^{-1}$ ); in the present study, exposure frequency was considered as 28 days year ${ }^{-1}$ corresponding to the June 2020 Saharan dust event; $T_{\exp }=$ the exposure duration 6 years for children and 24 years for adult; $A B W=$ average body weight, $15 \mathrm{~kg}$ for children and $70 \mathrm{~kg}$ for adults; $T_{\text {avrg }}=$ averaging time, for non-carcinogens $T_{\mathrm{avrg}}=T_{\exp } * 365$ days and for carcinogens $T_{\mathrm{avrg}}=70 \times 365$.

$C$ is the concentration of particulate matter $\left(\mu \mathrm{g} / \mathrm{m}^{3}\right) . C_{\mathrm{UCL}}$ estimates the reasonable maximum exposure, which is the upper limit of the $95 \%$ confidence interval for the mean. $C_{\mathrm{UCL}}$ was calculated based on the central limit theorem (adjusted) by USEPA (2002):

$C_{\mathrm{UCL}}=\bar{X}+\left(Z+\frac{\beta}{6 \sqrt{n}}\left(1+2 \times z^{2}\right)\right) S T D / \sqrt{n}$

where $\bar{X}=$ arithmetic mean; $\mathrm{Z}=$ statistic constant $1.645 ; \beta=$ skewness; $n=$ number of samples; and STD = standard deviation.

\section{Risk characterization}

Risk assessment for the carcinogenic and non-carcinogenic risk of PM was calculated using the parameter called hazard quotient (HQ), the ratio of CDI to reference dose (RfD) by using the following equation:

Hazard quotient $(\mathrm{HQ})=\mathrm{CDI} / \mathrm{RfD}(\mathrm{USEPA} 1989,2011)$

HQ of 1.0 is considered safe. HQ that is $<1.0$ indicates a negligible risk, i.e., the pollutant is not likely to induce adverse health effects, even to a sensitive individual. HQ $>1.0$ indicates that there may be some risks to sensitive individuals as a result of exposure (USEPA 1989, 2011). Given the lack of information regarding $\mathrm{RfD}$ of $\mathrm{PM}_{10}$ and $\mathrm{PM}_{2.5}$ in Mexico, we calculated RfD using the following equation:

$\mathrm{RfD}=\mathrm{RfC}\left(\right.$ inhalation reference concentration $\mu \mathrm{g} / \mathrm{m}^{3}$ ) $\times$ Assumed inhalation rate $\left(\mathrm{m}^{3} /\right.$ day $) \times 1 / \mathrm{BW}(\mathrm{kg})$

We used RfC values of $50 \mu \mathrm{g} / \mathrm{m}^{3}$ for $\mathrm{PM}_{10}$ and $5 \mu \mathrm{g} / \mathrm{m}^{3}$ for $\mathrm{PM}_{2.5}$ (de Oliveira et al. 2012; Li et al. 2017; Yunesian et al. 2019) to assess the probability of adverse health impacts.

\section{Results and discussion}

The daily average concentration of $\mathrm{PM}_{10}$ and $\mathrm{PM}_{2.5}$ during the June 2020 Saharan dust event from 15 monitoring stations is shown in Figs. 2 and 3. The daily average $\mathrm{PM}_{10}$ and $\mathrm{PM}_{2.5}$ levels were high during Saharan dust event and exceeded the annual limit of $75 \mu \mathrm{g} / \mathrm{m}^{3}$ and $45 \mu \mathrm{g} / \mathrm{m}^{3}$ set up by the Mexican standard Norm (NOM-020-SSA1-2014; DOF 2014). It also exceeded the WHO air quality guidelines for the annual mean concentrations of $50 \mu \mathrm{g} / \mathrm{m}^{3}$ and $25 \mu \mathrm{g} / \mathrm{m}^{3}$ for $\mathrm{PM}_{10}$ and $\mathrm{PM}_{2.5}$, respectively (WHO 2006).

In general, the $\mathrm{PM}_{10}$ and $\mathrm{PM}_{2.5}$ were at low concentrations before the dust event. As shown in Figs. 2 and 3, there was a significant increase in the daily average concentration of $\mathrm{PM}_{10}$ and $\mathrm{PM}_{2.5}$ in all the stations of Mexico under the examination period of Saharan dust event (23rd to 29th, June 2020). The elevated PM concentrations were as a result of received Saharan dust cover which is generally a rich source of $\mathrm{PM}_{10}$ and $\mathrm{PM}_{2.5}$. TAS and VAS 2 stations recorded the highest daily average concentration of $197 \mu \mathrm{g} / \mathrm{m}^{3}$ and $94 \mu \mathrm{g} / \mathrm{m}^{3}$ for $\mathrm{PM}_{10}$ and $\mathrm{PM}_{2.5}$, respectively. In contrast, MAS 6 and MAS 10 stations registered the lowest daily average concentration of $49 \mu \mathrm{g} / \mathrm{m}^{3}$ and $35 \mu \mathrm{g} / \mathrm{m}^{3}$ for $\mathrm{PM}_{10}$ and $\mathrm{PM}_{2.5}$, respectively. After the dust event, a considerable decrease in the PM concentrations (Figs. 2 and 3 ) was noted but the concentration of $\mathrm{PM}_{10}$ and $\mathrm{PM}_{2.5}$ remained high to those observed before the event. It can be explained by the fact that the effect of a Saharan dust event can extend to days succeeding the event as fine particulates can remain airborne for long durations.

Considering all days, $\mathrm{PM}_{10}\left(\mu \mathrm{g} / \mathrm{m}^{3}\right)$ average concentrations were 47, 42, and 53 for Nuevo Leon, Veracruz, and Tabasco; $\mathrm{PM}_{2.5}\left(\mu \mathrm{g} / \mathrm{m}^{3}\right)$ average concentrations were 20, 24, and 25 for Nuevo Leon, Veracruz, and Yucatan, respectively. It is noted that the increase in the concentration of PM was more significant on Saharan dust days as compared with the non-Saharan dust days. On Saharan dust days, average concentrations were 1.2, 2.2, and 2.2 times higher for $\mathrm{PM}_{10}$ than on non-Saharan dust days, with the values reaching $52 \mu \mathrm{g} / \mathrm{m}^{3}$, $68 \mu \mathrm{g} / \mathrm{m}^{3}$, and $86 \mu \mathrm{g} / \mathrm{m}^{3}$ for Nuevo Leon, Veracruz, and 

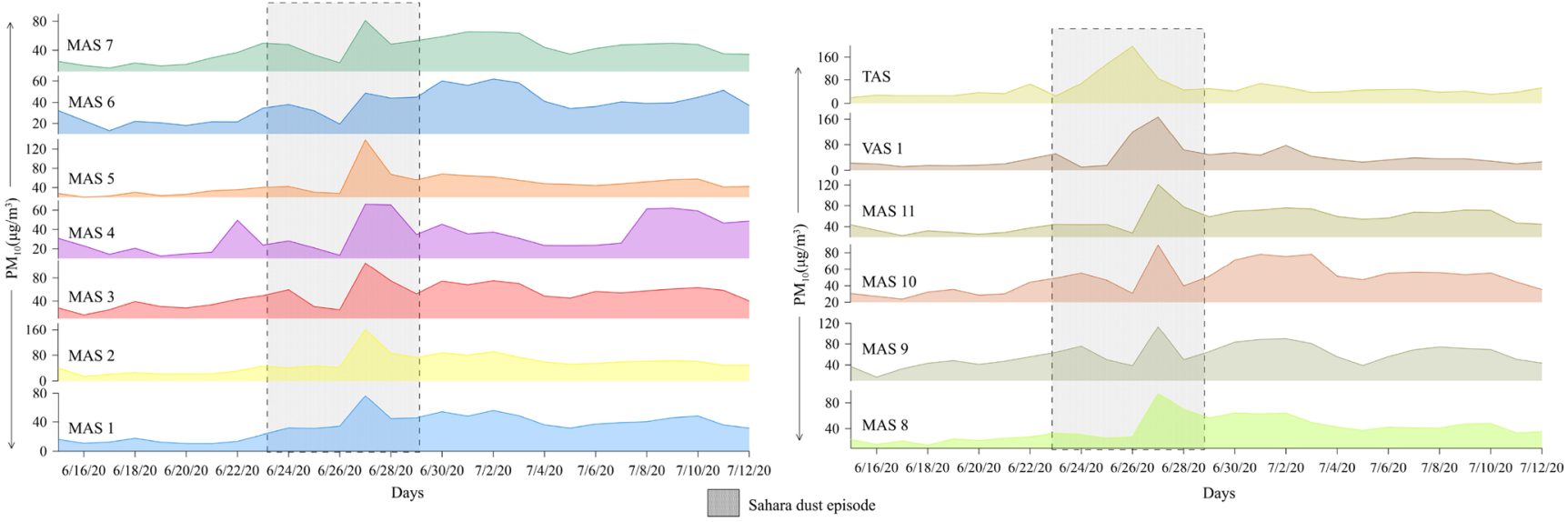

Fig. 2 Average $\mathrm{PM}_{10}$ concentrations from June 15 to July 12, 2020 recorded in air monitoring stations located in Nuevo Leon, Veracruz, and Tabasco of Mexico

Tabasco, respectively. Compared to non-Saharan dust days, the average concentrations of $\mathrm{PM}_{2.5}$ were $1.3,1.8$, and 2.4 times higher for Nuevo Leon, Veracruz, and Yucatan, with the values reaching $25 \mu \mathrm{g} / \mathrm{m}^{3}, 37 \mu \mathrm{g} / \mathrm{m}^{3}$, and $44 \mu \mathrm{g} / \mathrm{m}^{3}$, respectively. The results suggest that Tabasco and Yucatan have the highest average value of $\mathrm{PM}_{10}$ and $\mathrm{PM}_{2.5}$, followed by Veracruz and Nuevo Leon.

Next, we estimated the changes (\%) in $\mathrm{PM}_{10}$ and $\mathrm{PM}_{2.5}$ concentrations for the period of assessment, i.e., nonSaharan dust vs Saharan dust (Fig. 4). The first thing to note is that the variations of PM concentrations were obvious among the study regions, but it was uneven. The stations located in the coastal regions of Tabasco, Veracruz, and Yucatan presented higher increase percentage of PM levels in Saharan dust days than non-Saharan days. The station that registered the greatest change percentage was VAS 1 (118\%), followed by TAS (115\%) for $\mathrm{PM}_{10}$. YAS station recorded a maximum increase of about $59 \%$ for $\mathrm{PM}_{2.5}$. In contrary, the increase percentage of $\mathrm{PM}_{10}$ and $\mathrm{PM}_{2.5}$ concentrations varied between 5 and 45\%, respectively, in Nuevo Leon, displaying an overall increase of $20 \%$ of PM levels for the study period. For example, the increase of PM levels was higher in MAS 2 and MAS 1 between Saharan dust days and non-Saharan days, while it was least significant in MAS 10 station (Fig. 4). MAS 8 station displayed no significant variation between nonSaharan and Saharan dust days. It can be said that Nuevo Leon (located northeast) is less affected by Saharan dust event compared to other regions that are located on the southeast side of Mexico. This may be likely due to the differences in the dust intensity (significantly thicker dust), gravitational settling velocities, and distribution of Saharan dust across Mexico.

Additionally, the changes (\%) in $\mathrm{PM}_{10}$ and $\mathrm{PM}_{2.5}$ concentrations were examined with respect to previous major Saharan dust episodes in Mexico (Table 2). The lack of data availability from few air monitoring stations for previous year events, however, rendered a complete comparison to understand the effect of $\mathrm{PM}_{10}$ and $\mathrm{PM}_{2.5}$ concentrations between Saharan dust episodes. With available data, the first thing to note is that the $\mathrm{PM}_{10}$ and $\mathrm{PM}_{2.5}$ concentrations did not show

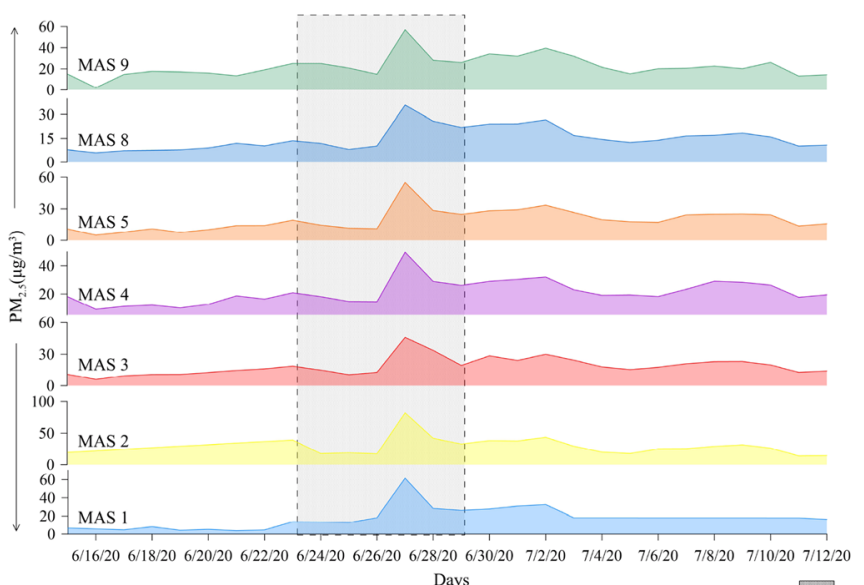

Days

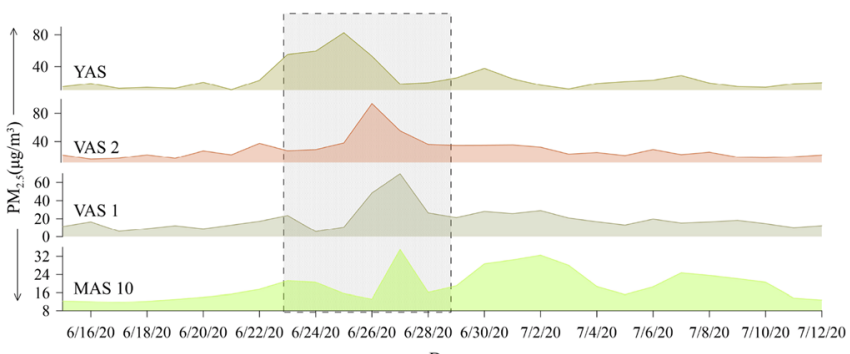

Days

Fig. 3 Average $\mathrm{PM}_{2.5}$ concentrations from June 15 to July 12, 2020 recorded in air monitoring stations located in Nuevo Leon, Veracruz, and Yucatan of Mexico 
Fig. 4 Bar chart displaying the changes (\%) in PM

concentrations between non-

Saharan and Saharan days

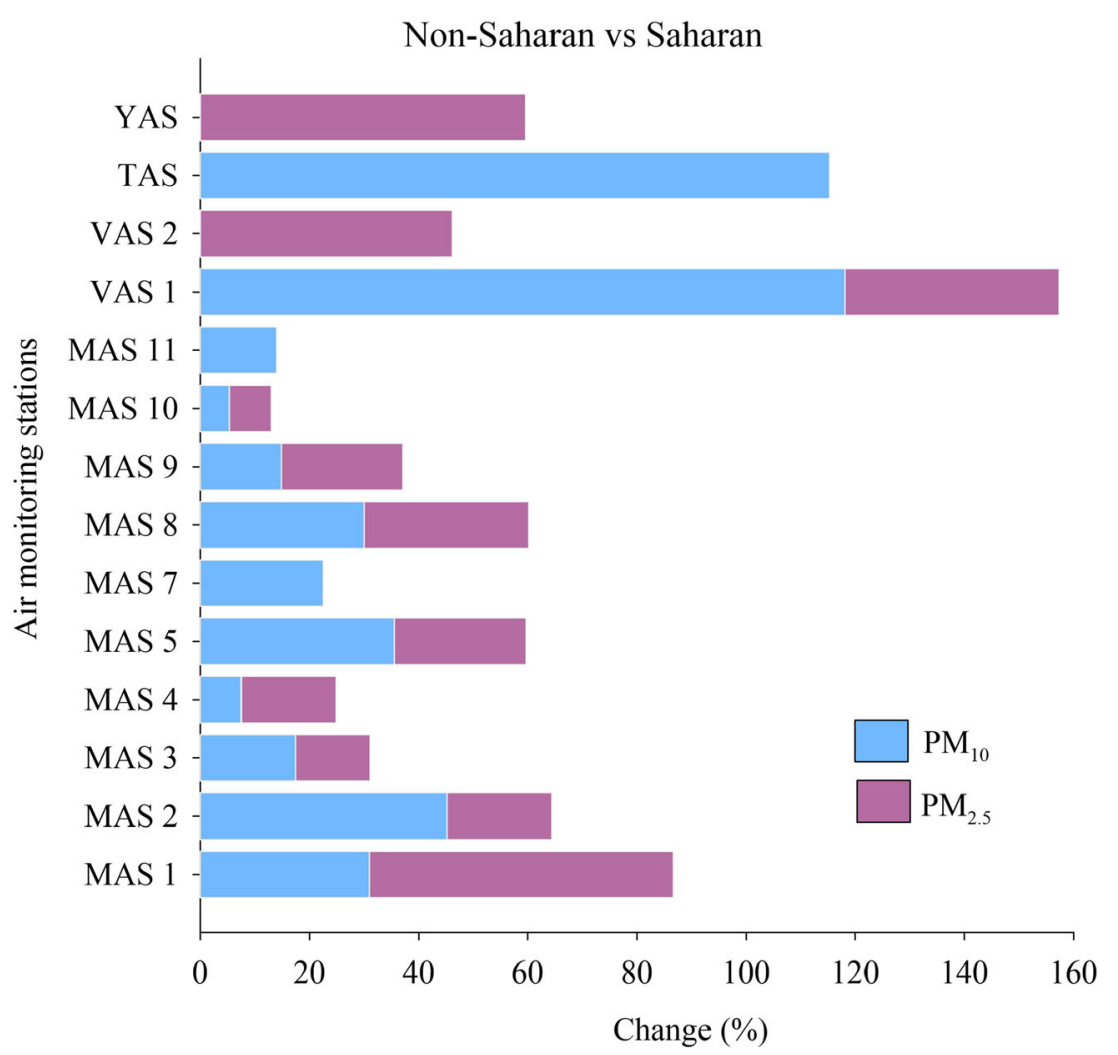

similar trends in each of the Saharan dust episodes. Despite certain differences observed in the concentrations, it is seen in Table 2 that all stations exceeded the concentrations of $\mathrm{PM}_{10}$ and $\mathrm{PM}_{2.5}$ with those of 2015,2018 , and 2019, except for MAS 1 . The change was noticeable with considerable increase, and it was well pronounced compared to previous Saharan dust episodes. For example, an average increase of $\mathrm{PM}_{10}$ by $8 \%$ and $71 \%$ was noted compared to years 2018 and 2019 in Nuevo Leon; in contrary, $\mathrm{PM}_{2.5}$ increased by $166 \%$ compared to 2019. When comparing 2019 with 2020, VAS1

Table 2 Comparison of PM concentrations between Saharan dust episodes for years 2015, 2018, 2019, and 2020 in Mexico

\begin{tabular}{|c|c|c|c|c|c|c|c|c|c|c|c|c|c|c|c|}
\hline \multicolumn{8}{|c|}{$\mathrm{PM}_{10}\left(\mu \mathrm{g} / \mathrm{m}^{3}\right)$} & \multicolumn{8}{|c|}{$\mathrm{PM}_{2.5}\left(\mu \mathrm{g} / \mathrm{m}^{3}\right)$} \\
\hline \multirow[t]{2}{*}{ Stations } & \multirow[t]{2}{*}{2020} & \multirow[t]{2}{*}{2019} & \multirow[t]{2}{*}{2018} & \multirow[t]{2}{*}{2015} & \multicolumn{3}{|c|}{ Relative change } & \multirow[t]{2}{*}{ Stations } & \multirow[t]{2}{*}{2020} & \multirow[t]{2}{*}{2019} & \multirow[t]{2}{*}{2018} & \multirow[t]{2}{*}{2015} & \multicolumn{3}{|c|}{ Relative change } \\
\hline & & & & & $\begin{array}{l}\text { A } \\
(\% \text { change })\end{array}$ & $\begin{array}{l}\mathrm{B} \\
\text { (\% change) }\end{array}$ & $\begin{array}{l}\mathrm{C} \\
\text { (\% change) }\end{array}$ & & & & & & $\begin{array}{l}\text { A } \\
(\% \text { change })\end{array}$ & $\begin{array}{l}\mathrm{B} \\
\text { (\% change) }\end{array}$ & $\begin{array}{l}\mathrm{C} \\
\text { (\% change) }\end{array}$ \\
\hline MAS 1 & 76 & 80 & 105 & 101 & -5 & -27 & -24 & MAS 1 & 62 & 25 & - & 42 & 146 & - & 47 \\
\hline MAS 2 & 160 & 66 & 97 & - & 143 & 65 & - & MAS 2 & 82 & 24 & 21 & 38 & 243 & 291 & 116 \\
\hline MAS 3 & 106 & 55 & 103 & 96 & 93 & 3 & 11 & MAS 3 & 46 & 19 & 32 & - & 142 & 43 & - \\
\hline MAS 4 & 66 & 46 & 89 & 87 & 44 & -26 & -24 & MAS 4 & 50 & 19 & - & - & 161 & - & - \\
\hline MAS 5 & 139 & 49 & 93 & 98 & 183 & 49 & 42 & MAS 5 & 55 & 18 & - & - & 206 & - & - \\
\hline MAS 6 & 49 & 41 & 89 & 87 & 19 & -45 & -44 & MAS8 & 36 & - & - & - & - & - & - \\
\hline MAS 7 & 81 & 62 & 71 & - & 31 & 14 & - & MAS 9 & 57 & 21 & - & - & 171 & - & - \\
\hline MAS 8 & 95 & 73 & 109 & 113 & 30 & -13 & -16 & MAS 10 & 35 & 18 & - & 47 & 95 & - & -25 \\
\hline MAS 9 & 113 & 60 & 85 & 104 & 89 & 33 & 9 & VAS 1 & 70 & 31 & 11 & - & 125 & 533 & - \\
\hline MAS 10 & 89 & 50 & 96 & 116 & 79 & -7 & -23 & VAS 2 & 94 & 31 & 45 & 40 & 203 & 109 & 135 \\
\hline MAS 11 & 121 & 67 & 85 & - & 81 & 43 & - & YAS & 83 & 52 & 35 & 49 & 59 & 136 & 69 \\
\hline VAS 1 & 167 & 69 & 90 & - & 142 & 86 & - & & & & & & & & \\
\hline TAS & 197 & 57 & 90 & - & 246 & 119 & - & & & & & & & & \\
\hline
\end{tabular}

A: change percentage with respect to PM concentrations between 2020 and 2019; B: change percentage with respect to PM concentrations between 2020 and 2018; C: change percentage with respect to PM concentrations between 2020 and 2015. The change in negative shows decreased contents and positive shows increased contents 
and VAS2 stations recorded $124 \%$ and $202 \%$ increase of $\mathrm{PM}_{2.5}$. The result of the analysis confirmed that the observed changes in the $\mathrm{PM}_{10}$ and $\mathrm{PM}_{2.5}$ concentrations are more severe during the June 2020 Saharan dust compared to previous episodes in Mexico.

It is reasonable to assume that the amount of dust entering the atmosphere in the region could worsen by the increased particulate concentrations. Therefore, it is critical to estimate air quality index for the Saharan dust period. As shown in Fig. 5 , in general, the distribution of air quality trend between the stations for $\mathrm{PM}_{10}$ remained good for most of the days but based on $\mathrm{PM}_{2.5}$, the dominance of moderate category was observed. In terms of $\mathrm{PM}_{2.5}$ estimations, it is suggested that the population of study area is exposed with more than $50 \%$ of the days with significant impact on health. It is important to note an elevated value in the category, "unhealthy" for all the stations on the maximum dusty day (June 27), leading to adverse air quality. The consequences of these inflations in air quality might have impact on health, especially on elderly and sensitive groups during COVID-19 pandemic.

Similar to our findings, variations in $\mathrm{PM}_{10}$ and $\mathrm{PM}_{2.5}$ levels during the Saharan dust events especially in the proximity of the source areas have been widely reported. Spain and Nicosia displayed $\mathrm{PM}_{10}$ concentrations reaching $250 \mu \mathrm{g} / \mathrm{m}^{3}$ and up to $470 \mu \mathrm{g} / \mathrm{m}^{3}$ respectively, during Saharan dust events (Querol et al. 2009; Achilleos et al. 2014). Moroni et al. (2015) identified 22 dust intrusions in Monte Martano (central Italy) in 2009 and estimated the impact of dust on $\mathrm{PM}_{10}$ at $22 \mu \mathrm{g} / \mathrm{m}^{3}$ per intrusion. Kabatas et al. (2014) also found a significant contribution of dust to high levels of $\mathrm{PM}_{10}$ in Turkey. Likewise, Dimitriou and Kassomenos (2018) observed extreme concentrations of $\mathrm{PM}_{10}$ in Athens (Greece) during April 2008 Saharan dust. We acknowledge here that our results of PM levels in Mexico were way lower compared to other regions during Saharan dust episodes (i.e., 2015, 2018, 2019 , and 2020) due to its geographical location away ( 7000 $\mathrm{km})$ from the source area. In addition, the lack of investigations for North American region closer to our study area, however, hinders a detailed comparison. In relation to meteorological conditions, Saharan dust events usually occur during warmer months (i.e., summer) characterized with higher temperatures and low relative humidity (Weinzierl et al. 2017; Ramírez-Romero et al. 2021). However, this region did not show any significant changes in temperature and relative humidity between Saharan dust days and non-Saharan dust days (Supplementary Material Table S1) similar to dust episodes witnessed in Athens, Greece, during 2001-2006 (Samoli et al. 2011), while a decrease in wind speed was observed during Saharan dust days favoring the accumulation of dust particles in atmosphere for a prolonged time. (a) MAS 1

\begin{tabular}{l|l|l|l|l|}
\cline { 2 - 5 } MAS 1 & 20 & 29 & 29 & 31 \\
\cline { 2 - 5 } MAS 2 & 42 & 37 & 43 & 39 \\
\hline MAS 3 & 45 & 53 & 28 & 23 \\
\cline { 2 - 5 } MAS 4 & 21 & 26 & 19 & 12 \\
\hline MAS 5 & 37 & 39 & 28 & 25 \\
\cline { 2 - 5 } MAS 6 & 31 & 35 & 30 & 18 \\
\hline MAS 7 & 45 & 44 & 31 & 20 \\
\hline
\end{tabular}

产 MAS

MAS

VAS 1

TAS

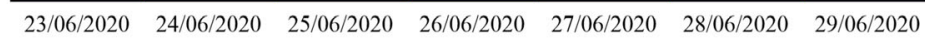

Days

(b)

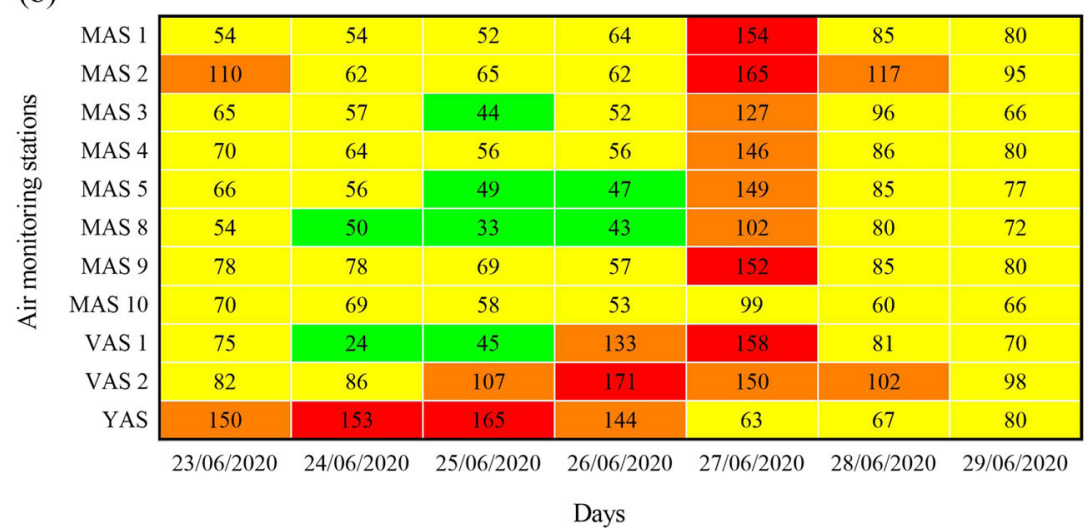

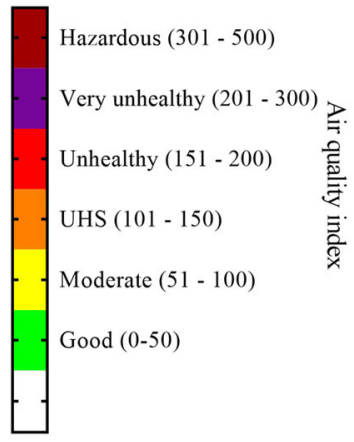

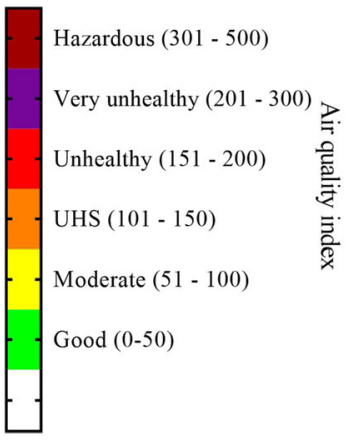

UHS: unhealthy for sensitive groups

Fig. 5 AQI levels for $\mathrm{PM}_{10}$ and $\mathrm{PM}_{2.5}$ concentration for the period of assessment (June 23-29, 2020) 
Owing to the fact that the COVID-19, by itself a respiratory disease and spread quickly among the community and SARSCoV-2 would remain viable and infectious in aerosols for hours (van Doremalen et al. 2020), this study determined the possible interrelationship between PM and COVID-19 cases and deaths for Nuevo Leon. By July 12, 2020, Nuevo Leon reported 12,322 confirmed COVID-19 cases and 694 deaths (Government of Mexico: https://coronavirus.gob.mx/datos/). The correlation analysis was performed for the entire study period (June 15, 2020 to July 12, 2020) considering the longer residence of PM levels in the atmosphere after the dust event (Figs. 2 and 3). Table 3 summarizes the association between PM and COVID-19 cases and death for the study period. Our results provided preliminary evidence showing that there is a prominent association of PM with COVID-19 cases and deaths during the Saharan dust event but only that of $\mathrm{PM}_{10}$ is significant. The fine fraction of $\mathrm{PM}\left(\mathrm{PM}_{2.5}\right)$ in our case did not present a substantial relation with COVID-19 cases and deaths (Table 3). Few studies reported similar results of less statistically significant association of $\mathrm{PM}_{2.5}$ particles with total or specific mortality. For example, in Barcelona (Spain), the effects of short-term exposure to $\mathrm{PM}_{2.5}$ were not significant during Saharan dust days (Perez et al. 2008). It was found, in Madrid and Italy, that the daily mean $\mathrm{PM}_{2.5}$ concentrations displayed no statistically significant association with total mortality, circulatory, and respiratory causes on Saharan dust days (Jiménez et al. 2010; Tobías et al. 2011; Mallone et al. 2011). Under reduced anthropogenic activities during pandemic measures, $\mathrm{PM}_{10}$ have presented strong relationship with COVID-19 mortality rate in many parts of the world (Yao et al. 2020; Setti et al. 2020; Shakoor et al. 2020; Kutralam-Muniasamy et al. 2020). Similarly, in this study, $\mathrm{PM}_{10}$ is positively correlated with COVID-19 cases and deaths $\left(r^{2}=0.53 ; 0.50\right)$, suggesting that exposure to such PM levels may affect COVID-19 prognosis, and thus, more comprehensive studies should be conducted on this subject.
Furthermore, to understand the human health risks associated with PM exposure during the study period, noncarcinogenic and carcinogenic risks in both children and adults via inhalation for Saharan dust and non-Saharan dust days were estimated by calculating the average $\mathrm{CDI}$ and $\mathrm{HQ}$. The results are shown in Table 4. The CDI values for noncarcinogenic risk of PM in children were comparatively higher than adults during Saharan period. For instance, the maximum CDI values $\left(\mu \mathrm{g} \mathrm{kg}^{-1}\right.$ day $\left.^{-1}\right)$ of non-carcinogenic risk for $\mathrm{PM}_{10}$ and $\mathrm{PM}_{2.5}$ in children were 4.4 and 0.38 (Tabasco), while for adults was only 2.48 (Tabasco) and 1.16 (Yucatan), respectively. It has been documented that children are highly vulnerable to environmental pollutants than adults for numerous reasons, including their relatively higher amount of air inhalation (the air intake per weight unit of a resting infant is twice that of an adult), and their immune system and lungs not being fully developed (Thabethe et al. 2014; Morakinyo et al. 2017). Contrarily, for carcinogenic risks, adults displayed maximum CDI values $\left(\mu \mathrm{g} \mathrm{kg}^{-1}\right.$ day $^{-1}$ ) of 0.85 (Tabasco) and 0.40 (Yucatan), and children exhibited 0.38 (Tabasco) and 0.18 (Yucatan) values for $\mathrm{PM}_{10}$ and $\mathrm{PM}_{2.5}$. Among regions studied, Veracruz, Tabasco, and Yucatan during Saharan dust days presented nearly one-fold to two-fold increase in CDI values for both children and adults compared to non-Saharan dust days. Nuevo Leon also presented greater CDI values; however, it was in lesser extent compared to other regions. As mentioned earlier in this study, it could be attributed to the location of Nuevo Leon (northeast), which experienced lesser impact from Saharan dust event in comparison with other three regions (southeast) in Mexico. In case of HQ, both children and adults displayed values higher for $\mathrm{PM}_{2.5}$ compared to $\mathrm{PM}_{10}$ (Table 4). It is important to mention here that the AQI values for $\mathrm{PM}_{2.5}$ fell into the category of moderate-unhealthy for most Saharan dust days. Fine fraction of PM particles $\left(\mathrm{PM}_{2.5}\right)$ are more resident in the atmosphere and they more

Table 3 Correlation between daily confirmed COVID-19 cases and deaths and particulate matter in Nuevo Leon (Mexico)

\begin{tabular}{|c|c|c|c|c|c|c|c|c|}
\hline & $\mathrm{PM}_{10}$ & $\mathrm{PM}_{2.5}$ & Total number of cases & Male cases & Female cases & Total number of deaths & Male deaths & Female deaths \\
\hline $\mathrm{PM}_{10}$ & 1.00 & & & & & & & \\
\hline $\mathrm{PM}_{2.5}$ & $0.96^{* \dagger 末}$ & 1.00 & & & & & & \\
\hline Total number of cases & $0.53^{* \dagger}$ & 0.33 & 1.00 & & & & & \\
\hline Male cases & $0.48^{* \dagger}$ & 0.33 & $0.69^{*+*}$ & 1.00 & & & & \\
\hline Female cases & $0.43^{*}$ & 0.27 & $0.75^{*+\hbar}$ & $0.96^{*+1}$ & 1.00 & & & \\
\hline Total number of deaths & $0.50^{* \dagger}$ & 0.30 & $1.00^{*+*}$ & $0.68^{*+1}$ & $0.75^{* \dagger \dagger}$ & 1.00 & & \\
\hline Male deaths & $0.40^{*}$ & 0.25 & $0.73^{*+*}$ & $0.57^{*+1}$ & $0.62^{* \dagger+}$ & $0.73^{*+*}$ & 1.00 & \\
\hline Female deaths & $0.45^{*}$ & 0.31 & $0.78^{*+1}$ & $0.57^{*+1}$ & $0.65^{*+\dagger}$ & $0.79^{*+\dagger}$ & $0.57^{*+\dagger}$ & 1.00 \\
\hline
\end{tabular}




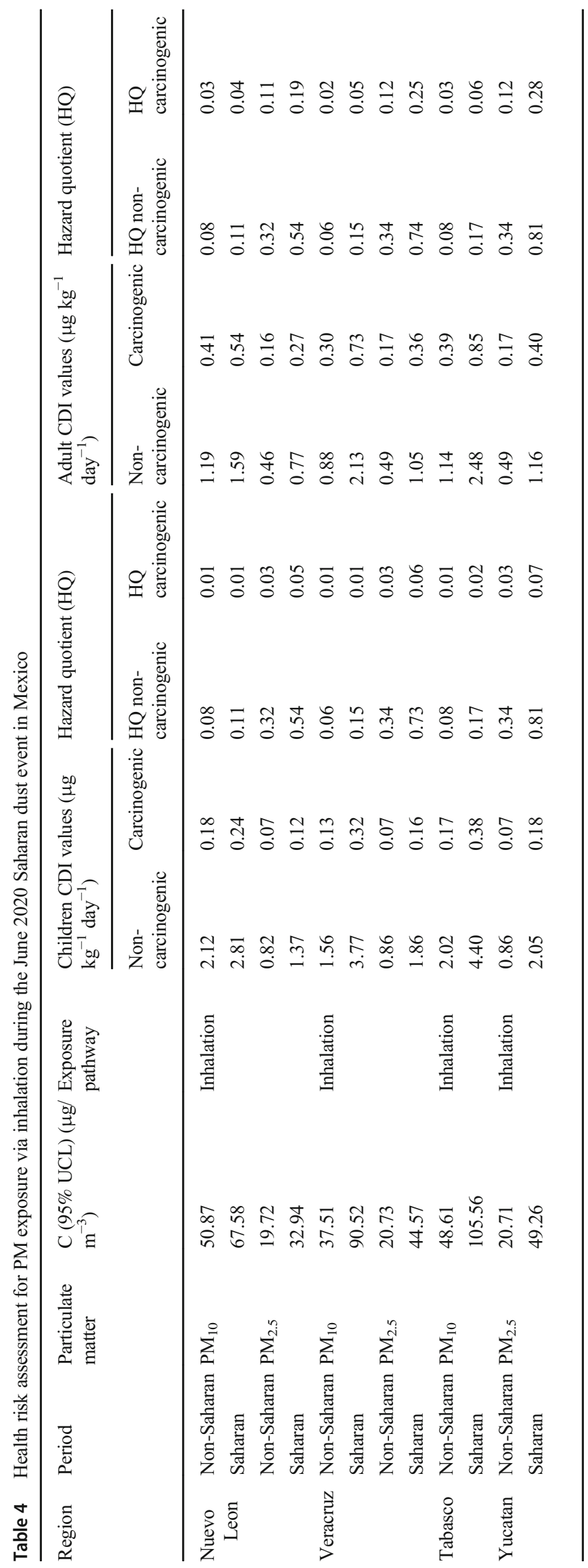


easily penetrate the respiratory system (Xing et al. 2016) which is a deep concern and demands in-depth investigation of health risks associated with $\mathrm{PM}_{2.5}$. In general, HQ values were similar on non-Saharan days, whereas a potential increase in HQ values closer to 1 was seen in all the four studied regions during Saharan dust days. Therefore, our results from human health risk assessment about the levels and risks of PM could make useful contributions to government, environmental, and health professionals in taking good steps to protect and promote human health during this pandemic situation.

\section{Limitations of the study}

Although our study data and correlational analysis showed significant impacts of PM from Saharan dust in COVID-19, this short communication has a few limitations: (1) additional information on meteorological factors such as temperature, precipitation, and relative humidity were not examined, and future studies need to explore these factors for a comprehensive investigation. (2) PM samples from the June 2020 Saharan dust event were not analyzed by scanning electron microscopy with energy dispersive X-ray spectrometry and inductively coupled plasma mass spectrometry for morphological and chemical characterization. These results would have been greatly helpful but could not be accomplished as the COVID-19 pandemic hindered the analyses. Accordingly, the chemical composition of PM was not considered for assessing the health associated risks, and as a result, the exposure to the combination of the pollutants could not be determined. Thus, the toxic effects of these PM particles during the short-term dust episodes should be further investigated. (3) This study could not consider population density, mobility trends from the regions studied in the analysis. Future studies can investigate on these aspects to provide more useful insights into the spread of COVID-19. (4) The lack of studies for comparison demands future studies from other world regions that are similarly affected by the June 2020 Saharan dust event.

\section{Concluding remarks}

In summary, this study is the first to quantitatively assess the importance of the June 2020 Saharan dust event over PM concentrations in Mexico, as well to investigate its relationship with COVID-19 pandemic. As a consequence of the June 2020 Saharan dust event, we observed a sudden hike in both $\mathrm{PM}_{10}$ and $\mathrm{PM}_{2.5}$ concentrations from northeastern and southeastern regions of Mexico. Also, in these regions, the PM levels were higher in many orders of magnitude compared to previous major Saharan dust episodes. Based on our results, it is confirmed that the Saharan dust transported from longer distances had a significant effect on the PM concentrations in Mexico. The correlational analysis revealed that the Saharan dust contributions to increased $\mathrm{PM}_{10}$ levels present positive association with the daily number of COVID-19-confirmed cases and deaths. In parallel, this study provided a valuable evaluation of the human health risks associated with exposure to PM via inhalation in both children and adults during the dust event. Overall, the main findings of this study underline that the Saharan dust events cannot be ignored during global health crisis. Taking together, this study could serve as a reference data for government authorities to design appropriate strategies for mitigating such unforeseen episodes to improve air quality.

Supplementary Information The online version contains supplementary material available at https://doi.org/10.1007/s11356-021-14168-y.

Acknowledgements VCS thanks CONACYT project no. 274276 "Fase I De La Remediación de Áreas Contaminadas Con Hidrocarburos En La Refinería Gral. Lázaro Cárdenas" for Postdoctoral fellowship. The authors would like to acknowledge all the doctors, health-care professionals, police personnel, sanitation workers, and waste collectors at the frontlines working silently and tirelessly during COVID-19 outbreak worldwide. We also thank Sistema Nacional de Información de la Calidad del Aire, operated by Instituto Nacional de Ecologia y Cambio Climatico, Government of Mexico for making air quality data open access.

Availability of data and materials The datasets generated and/or analyzed during the current study are available in the Sistema Nacional de Información de la Calidad del Aire repository, operated by Instituto Nacional de Ecologia y Cambio Climatico, Government of Mexico (SINAICA, https://sinaica.inecc.gob.mx/index.php).

Author contribution V.C. Shruti-conceptualization, methodology, data curation, writing-original draft; Gurusamy Kutralam-Munaisamy-conceptualization, methodology, data curation, writing-original draft; Fermín Pérez-Guevara-methodology, conceptualization; I. Elizalde Martinezsupervision.

\section{Declarations}

Ethics approval and consent to participate Not applicable.

Consent for publication Not applicable.

Competing interests The authors declare no competing interests.

\section{References}

Achilleos S, Evans JS, Yiallouros PK, Kleanthous S, Schwartz J, Koutrakis P (2014) PM10 concentration levels at an urban and background site in Cyprus: the impact of urban sources and dust storms. J Air Waste Manage Assoc 64(12):1352-1360

Ali-Khodja H, Kadja M, Terrouche A, Lokorai K (2017) Identification of anthropogenic and natural sources of atmospheric particulate matter and trace metals in Constantine. Algeria J Earth Sci Geotech Eng 7(1):231-240 
Bretón RM, Bretón JG, Kahl J, Lara ER, Quiroz AV, Guzmán AA, García MM, Hernández GG, Canul JA, Guzmán AR (2018) Atmospheric N and S Deposition fluxes in the Metropolitan Area of Monterrey, Mexico and its relation with criteria air pollutants and meteorological conditions. InAir Pollution-Monitoring, Quantification and Removal of Gases and Particles. IntechOpen

Çapraz Ö, Deniz A (2020) Particulate matter (PM 10 and PM 2.5) concentrations during a Saharan dust episode in Istanbul. Air Qual Atmos Health:1-8

Coker ES, Cavalli L, Fabrizi E, Guastella G, Lippo E, Parisi ML, Pontarollo N, Rizzati M, Varacca A, Vergalli S (2020) The effects of air pollution on COVID-19 related mortality in Northern Italy. Environ Resour Econ 76(4):611-634

CONAGUA (2020) Nube de polvo del Sahara pasará sobre la Península de Yucatán y la vertiente del Golfo de México durante esta semana.

de Oliveira BFA, Ignotti E, Artaxo P, do Nascimento Saldiva PH, Junger WL, Hacon S, (2012) Risk assessment of PM 2.5 to child residents in Brazilian Amazon region with biofuel production. Environ Health 11(1):1-11

Dimitriou K, Kassomenos P (2018) Day by day evolution of a vigorous two wave Saharan dust storm-thermal and air quality impacts. Atmósfera 31(2):105-124

DOF (Diario Oficial de la Federación) (2014) Valores límites permisibles para la concentración de partículas suspendidas PM10 y PM2.5 en el aire ambiente y criterios para su evaluación. Norma Oficial Mexicana NOM-025-SSA1-2014. Available online: http://www. aire.cdmx.gob.mx/descargas/monitoreo/normatividad/NOM-025SSA1-2014.pdf

González-Santiago O, Badillo-Castaneda CT, Kahl JD, Ramírez-Lara E, Balderas-Renteria I (2011) Temporal analysis of PM10 in metropolitan Monterrey, México. J Air Waste Manag Assoc 1 61(5):573-579

Hernández-Escamilla JA, Flores-Margez JP, Shukla MK (2015) Particulate matter: capture and quantification in natural and anthropogenic sources. J Environ Anal Toxicol 5(281):2161-0525

Jiménez E, Linares C, Martínez D, Díaz J (2010) Role of Saharan dust in the relationship between particulate matter and short-term daily mortality among the elderly in Madrid (Spain). Sci Total Environ 408(23):5729-5736

Kabatas B, Unal A, Pierce RB, Kindap T, Pozzoli L (2014) The contribution of Saharan dust in PM10 concentration levels in Anatolian Peninsula of Turkey. Sci Total Environ 488-489:413-421

Kim KH, Kabir E, Kabir S (2015) A review on the human health impact of airborne particulate matter. Environ Int 74:136-143

Kutralam-Muniasamy G, Pérez-Guevara F, Roy PD, Elizalde-Martínez I, Shruti VC (2020) Impacts of the COVID-19 lockdown on air quality and its association with human mortality trends in megapolis Mexico City. Air Qual Atmos Health 28:1-0

Li F, Xiao M, Zhang J, Yang J, Zhu L (2017) Health risk assessment on tunnel workers' exposure to PM10 based on triangular fuzzy numbers. In AIP Conference Proceedings 1820(1):040011

Loxham M, Nieuwenhuijsen MJ (2019) Health effects of particulate matter air pollution in underground railway systems-a critical review of the evidence. Particle Fibre Toxicol 16(1):1-24

Mallone S, Stafoggia M, Faustini A, Gobbi GP, Marconi A, Forastiere F (2011) Saharan dust and associations between particulate matter and daily mortality in Rome, Italy. Environ Health Perspect 119(10): 1409-1414

Molina LT, Velasco E, Retama A, Zavala M (2019) Experience from integrated air quality management in the Mexico City metropolitan area and Singapore. Atmosphere 10:512

Morakinyo OM, Adebowale AS, Mokgobu MI, Mukhola MS (2017) Health risk of inhalation exposure to sub-10 $\mu \mathrm{m}$ particulate matter and gaseous pollutants in an urban-industrial area in South Africa: an ecological study. BMJ Open 7(3):e013941

Moroni B, Castellini S, Crocchianti S, Piazzalunga A, Fermo P, Scardazza F, Cappelletti D (2015) Ground-based measurements of long-range transported aerosol at the rural regional background site of Monte Martano (Central Italy). Atmos Res 155:26-36

Perez L, Tobias A, Querol X, Künzli N, Pey J, Alastuey A, Viana M, Valero N, González-Cabré M, Sunyer J (2008) Coarse particles from Saharan dust and daily mortality. Epidemiology 19:800-807

Querol X, Pey J, Pandolfi M, Alastuey A, Cusack M, Moreno T, Viana M, Mihalopoulos N, Kallos G, Kleanthous S (2009) African dust contributions to mean ambient PM10 levels across the Mediterranean Basin. Atmos Environ 43:4266-4277

Querol X, Tobías A, Pérez N, Karanasiou A, Amato F, Stafoggia M, García-Pando CP, Ginoux P, Forastiere F, Gumy S, Mudu P (2019) Monitoring the impact of desert dust outbreaks for air quality for health studies. Environ Int 130:104867

Ramírez-Romero C, Jaramillo A, Córdoba MF, Raga GB, Miranda J, Alvarez-Ospina H, Rosas D, Amador T, Kim JS, Yakobi-Hancock J, Baumgardner D (2021) African dust particles over the western Caribbean-Part I: Impact on air quality over the Yucatán Peninsula. Atmos Chem Phys 21(1):239-253

Samoli E, Kougea E, Kassomenos P, Analitis A, Katsouyanni K (2011) Does the presence of desert dust modify the effect of PM10 on mortality in Athens, Greece? Sci Total Environ 409(11):2049-2054

Setti L, Passarini F, De Gennaro G, Barbieri P, Perrone MG, Piazzalunga A, Borelli M, Palmisani J, Di Gilio A, Piscitelli P, Miani A (2020) The potential role of particulate matter in the spreading of COVID19 in Northern Italy: first evidence-based research hypotheses. https://www.medrxiv.org/content/10.1101/2020.04.11.20061713v1

Shakoor A, Chen X, Farooq TH, Shahzad U, Ashraf F, Rehman A, e Sahar N, Yan W (2020) Fluctuations in environmental pollutants and air quality during the lockdown in the USA and China: two sides of COVID-19 pandemic. Air Qual Atmos Health:1-8

Thabethe NDL, Engelbrecht JC, Wright CY, Oosthuizen MA (2014) Human health risks posed by exposure to PM10 for four life stages in a low socio-economic community in South Africa. Pan Afri Med $\mathrm{J} 18$

Tobías A, Pérez L, Díaz J, Linares C, Pey J, Alastruey A, Querol X (2011) Short-term effects of particulate matter on total mortality during Saharan dust outbreaks: a case-crossover analysis in Madrid (Spain). Sci Total Environ 412:386-389

USEPA (1989) Risk Assessment Guidance for Superfund (RAGS): Human health evaluation manual (Part F), Office of Solid Waste Emergency Response, Washington DC, America

USEPA (1999) Guideline for reporting of daily air quality -Air Quality Index (AQI). Office for Air Quality Planning and Standards, United States Environmental Protection Agency, North Carolina, USA. http://www.epa.gov/ttn/-oarpg/t1/memoranda/rg701.pdf.

USEPA (2002) Calculating upper confidence limits for exposure point concentrations at hazardous waste sites OSWER 9285610Washington, DC: Office of Emergency and Remedial Response, US Environmental Protection Agency; 20460, December 2002

USEPA (2009) Risk assessment guidance for superfund. In: Human Health Evaluation Manual (Part F, Supplemental Guidance for Inhalation Risk Assessment), vol. I. Office of Superfund Remediation and Technology Innovation

USEPA (2011) Exposure factors handbook 2011 edition EPA/600/R-09/ 052F Washington, DC: National Center for Environmental Assessment, Office of Research and Development, US Environmental Protection Agency; 201120460

van Doremalen N, Bushmaker T, Morris DH, HolbrookMG GA, Williamson BN, Tamin A, Harcourt JL, Thornburg NJ, Gerber SI (2020) Aerosol and surface stability of SARS-CoV-2 as compared with SARS-CoV-1. New Engl J Med 382:1564-1567

Weinzierl B, Ansmann A, Prospero JM, Althausen D, Benker N, Chouza F, Dollner M, Farrell D, Fomba WK, Freudenthaler V, Gasteiger J (2017) The Saharan aerosol long-range transport and aerosol-cloud- 
interaction experiment: overview and selected highlights. Bull Am Meteorol Soc 98(7):1427-1451

WHO (2006) Air Quality Guidelines, Global Update 2005; World Health Organization: Geneva, Switzerland, 2006; p. 22. Available online: https://www.who.int/phe/health_topics/outdoorair/outdoorair_aqg/ en/

WHO (2018) http://www.who.int/news-room/detail/02-05-2018-9-outof-10-people-worldwide-breathe-polluted-air-but-more-countriesare-taking-action

WHO (2020) Report of the WHO-China Joint Mission on Coronavirus Disease 2019 (COVID-19). https://www.who.int/docs/defaultsource/coronaviruse/who-china-joint-mission-on-covid-19-finalreport.pdf

Wu X, Nethery RC, Sabath MB, Braun D, Dominici F (2020) Exposure to air pollution and COVID-19 mortality in the United States. Available online: https://projects.iq.harvard.edu/covid-pm
Xing YF, Xu YH, Shi MH, Lian YX (2016) The impact of PM2. 5 on the human respiratory system. J Thorac Dis 8(1):E69

Yao Y, Pan J, Wang W, Liu Z, Kan H, Meng X, Wang W (2020) Spatial correlation of particulate matter pollution and death rate of COVID19/China/PM25. PM10/multiple linear regression medRxiv. https://doi.org/10.1101/2020.04.07.20052142

Yunesian M, Rostami R, Zarei A, Fazlzadeh M, Janjani H (2019) Exposure to high levels of PM2. 5 and PM10 in the metropolis of Tehran and the associated health risks during 2016-2017. Microchemical J. 150: 104174

Publisher's note Springer Nature remains neutral with regard to jurisdictional claims in published maps and institutional affiliations. 